\title{
PERFOMNCE, INTESTINE MORPHOLOGY AND SERUM BIOCHEMISTRY OF BROILER CHICKENS TO DELAYED POST HATCH FEEDING
}

\author{
MERKhan M. MUSTAFA \\ Dept. of Animal production, College of Agricultural Engineering Science, University of Duhok. \\ Kurdistan region-Iraq
}

(Received: October 17, 2021; Accepted for Publication: November 10, 2021 )

\begin{abstract}
This study was conducted to estimate the effect of delayed post hatch feeding after arrival to the rearing hall on broiler performance, serum biochemistry and jejunum histology. A total of 225 Ross 308 day-old chicks were randomly distributed into three groups T1 chicks access to feed immediately, T2 chicks delayed in feeding for 12 hours and T3 chicks delayed in feeding for 24 hours with three replicates of 25 chicks. Remained yolk sack was lower for chicks that had immediate access to feed compared to other experimental groups. Longer delay feeding time lowered body weight uniformity \% at different ages. Immediate access to feed significantly $(P<0.05)$ improved broiler performance at different ages compared to that delayed for 12 and 24 hours post hatch. Significantly $(P<0.05)$ longer small intestine and higher percent of live body weight were recorded for early feeding groups compared to delayed groups. The level of T3 and T4 hormones in the serum were significantly $(\mathbf{P}<0.01)$ higher for early feeding groups compared to other groups. Increasing delayed post hatch feeding led to a significant $(P<0.01)$ increase in uric acid level in serum. Early feeding significantly $(\mathbf{P}<0.01)$ improved jejunum histology including villi height, villi width, villi height to crypt depth and surface area.
\end{abstract}

KEY WORDS: broiler, early feeding, performance, intestine histology

\section{INTRODUCTION}

$\mathbf{H}$ atch window 21 days of incubation is the range in which a broiler chicks need to get hatched in the hatchery machine, having 24 to 48 hours as an approximate to complete the entire process (Jacobs et al., 2016). Incubation conditions and age of the parent are the some of the many other factors that affect the hatching process of a chick (Lourens et al., 2005). During this process, hatching, chicks have no access to water or feed unless they are in the field which is the beginning of their performance and health (Simon et al., 2015). Simultaneous pulling and processing of the chicks for example; vaccination, counting, sexing, and sorting are done at the end of the hatch window. According to the standard guidance, they are sorted for about 1-4 hours before transferring them to the broiler farms. Intestinal improvement (Lilburn and Loeffler, 2015) as well as immunological development (Panda et al., 2014) have been claimed by providing immediate feed and water in the post-hatch stage. However, studies showed that this process may be useless in later stage of life and lead to unclear benefit of immediate feeding of the chicks (Gonzales et al., 2003; Simon et al., 2014, 2015). In practical, early nutrition is done through providing the nutrition (feed and water) in the hatcher which is called on-farm hatching in which the chick is hatched within broiler house unit. According to some researches, production performance of the chicks may be negatively affected if they transported to the field in 1-day old and this depending on the transport period which may lead to disability of the chick to adapt to the stress and deprivation of feed (Bergoug et al., 2013; Jacobs et al., 2016). Although residual egg yolk is a good source of nutrition, commercial broiler chicks cannot obtain sufficient nutritional requirements from this source. Furthermore, delay provision of feed may reduce villus height, villus width a surface area, crypt depth or percentage of cell proliferation in the chicks which are the main affected morphological changes in chicks (Shinde et al., 2015; Ghanem et al., 2018). 
Therefore, the aim of this experiment was to study the influence of delaying post hatch feeding on performance, intestine morphology and serum biochemical of broiler chicks.

\section{MATERIAL AND METHOD}

\subsection{Subjects and experimental design}

Two hundred and twenty five day old chicks (Ross 308) were provided by a local hatchery. After arrival, chicks were weighed. They were equally and randomly distributed to different delayed feeding time after arrived to rearing hall. T1 0 (feeding immediately) T2 delayed feeding for 12 hours and T3 delayed feeding for 24 hours. Each group was replicated three times $(25$ chicks each). Birds were reared in $(1 \mathrm{~m} \mathrm{x} 1 \mathrm{~m})$ floor pens. The halls were equipped with essential equipment's including heating facilities and adjustable setting of temperature. The starter diet was provided to birds from 1- 14 days of age. Later, from 14-21 days, the birds were fed on the grower diet. Ad libitum feed and water were provided to the birds (Table 1).

Table (1): The composition of the starter and grower diets

\begin{tabular}{|c|c|c|}
\hline Ingredients (kg) & $\begin{array}{l}\text { Starter (kg/ton) } \\
\text { 1- } 14 \text { days }\end{array}$ & $\begin{array}{l}\text { Grower (kg/ton) } \\
14-21 \text { days }\end{array}$ \\
\hline Corn & 471.05 & 493.55 \\
\hline Wheat flour & 50 & 50 \\
\hline Wheat bran & 40 & 50 \\
\hline Soybean meal $46 \%$ & 370 & 340 \\
\hline oil & 23 & 24 \\
\hline limestone & 10 & 8 \\
\hline Di calcium phosphate & 7 & 6 \\
\hline DL methionine & 0.200 & 0.200 \\
\hline L- Iysine & 1 & 0.5 \\
\hline Anti-toxin & 1 & 1 \\
\hline Salt & 1 & 1 \\
\hline Premix ${ }^{1}$ & 25 & 25 \\
\hline Anti coccidial & 0.250 & 0.250 \\
\hline Enzyme & 0.5 & 0.5 \\
\hline Total & 1000 & 1000 \\
\hline \multicolumn{3}{|c|}{ Estimated chemical composition } \\
\hline Moisture (\%) & 11.57 & 11.78 \\
\hline Crude protein (\%) & 22.49 & 20.65 \\
\hline Energy Kcal/kg & 2966 & 3055 \\
\hline Fat $(\%)$ & 2.97 & 3.36 \\
\hline Fiber (\%) & 2.18 & 2.64 \\
\hline Ash (\%) & 4.83 & 3.34 \\
\hline Starch (\%) & 44.22 & 46.29 \\
\hline Sugars (\%) & 4.02 & 3.87 \\
\hline Calcium (\%) & 1.12 & 0.97 \\
\hline Available phosphorous (\%) & 0.58 & 0.53 \\
\hline
\end{tabular}

\subsection{Performance measurements}

Performance parameter (Body Weight, Feed Intake (FI), Feed Conversion ratio) were measured weekly. However, the relative weight of internal organ, the mortality and production index were measured at 21 days of the experiment.

\subsection{Yolk sac measurement}

At day1, 4 and 7 days of age 2 chicks from each replicate were randomly selected and yolk sac was measured as a percent of the live body weight according to equation (yolk sac weight/ live body weight * 100).

\subsection{Body weight uniformity percent}

At the end of each week all chicks were individually weighted and the body weight uniformity percentage of each replicate was recorded according to equation (number of chicks weight within $\pm 10 \%$ of mean/ total number of chicks*100)

\subsection{Histology of intestine (jejunum)}

Jejunum tissue samples were collected, samples were flushed with saline buffered and the $10 \%$ neutral buffered formalin has been used to fix the samples. The eosinin and haematoxylin have been used to stain the sectioned samples after coalition into separation and paraffin wax. The tissue sections that have been prepared were image captured by digital camera at $10 \times$ magnification under (Dino-Eye-Microscope Eye-piece 38 Camira). The morphometric indices were determined by using Dino-eye program. The photos were digitized and the 
measurement parameters recorded according to (Iji et al., 2001)./

\subsection{Serum biochemical parameters}

The serum parameters were determined at 21 days of age according to (Mustafa et al., 2021) . Blood samples from two birds per cage were obtained by venipuncture of the jugular vein at 21 days of age. Then, the blood keep cold and transferred to lab where they will centrifuge at $1500 \mathrm{~g}$ for $10 \mathrm{~min}$. The serum was harvested and stored at $-20{ }^{\circ} \mathrm{C}$ until analysis. Triglyceride, glucose, Globulin, Total protein, Albumin, Cholesterol, LDL, HDL, ALT, AST, T3, T4, and uric acid were measured using auto analyzer (Cobas 6000, Roche Diagnostics. Germany).

\subsection{Statistical analysis}

Data collected were subjected to one Way ANOVA using SAS ( 2010),Differences among means were determined using Duncan's multiple ranges test (Duncan, 1955).

\section{RESULTS AND DISCUSSION}

3.1 Yolk sac percent of live body weight Figure 1 represents the effect of different feeding time after chicks arrived to the rearing hall on the remained yolk sac as a percent of live body weight. Its shows that higher yolk sac remained at 4 and 7 days of age was for chicks that were delayed feeding for 24 hours followed by those that were accessed to feed after 12 hours. Lower yolk sac percentage at both ages was for chicks that were immediately feed after placement in the rearing hall. Similar results were obtained by (Bhanja et al., 2009: Cardeal et al., 2020) reported that higher yolk sac percent of live body weight was found in birds that were delayed to the access of feed for 24 hours compared to those that were feed immediately. In contrast Ozlu et al., (2020) mentioned that delay chicks feeding time decreased the yolk sac percent of live body weight compared to those feed early. Moreover, Williams et al., (2021) reported that yolk sac percent of live body weight did not significantly affected by the delay feeding time for 24 hours compared to 3 hours. Rapid yolk sac absorption in chicks fed diet immediately is due to presence of feed in the gastrointestinal tract which accelerates secretion of the yolk sac in to the small intestine and raised uptake mechanisms for hydrophilic compounds. Previous trial reported that by this antiperistalsis movements move the digesta proximally toward the gizzard (Esteban et al., 1991). These intestinal movements resulted in increased amounts of yolk content in the proximal small intestine after hatching (Noy and Sklan, 1998a).

High resorption of the yolk sac is generally considered positive for chicken development and has been suggested to stimulate the transport of immunoglobulins from the yolk to the chicken (Moran and Reinhart, 1980) Early feeding after hatching, compared with delayed feeding, appears to stimulate yolk utilization, as reported by (Speake et al. 1998;Bhanja et al. 2009).

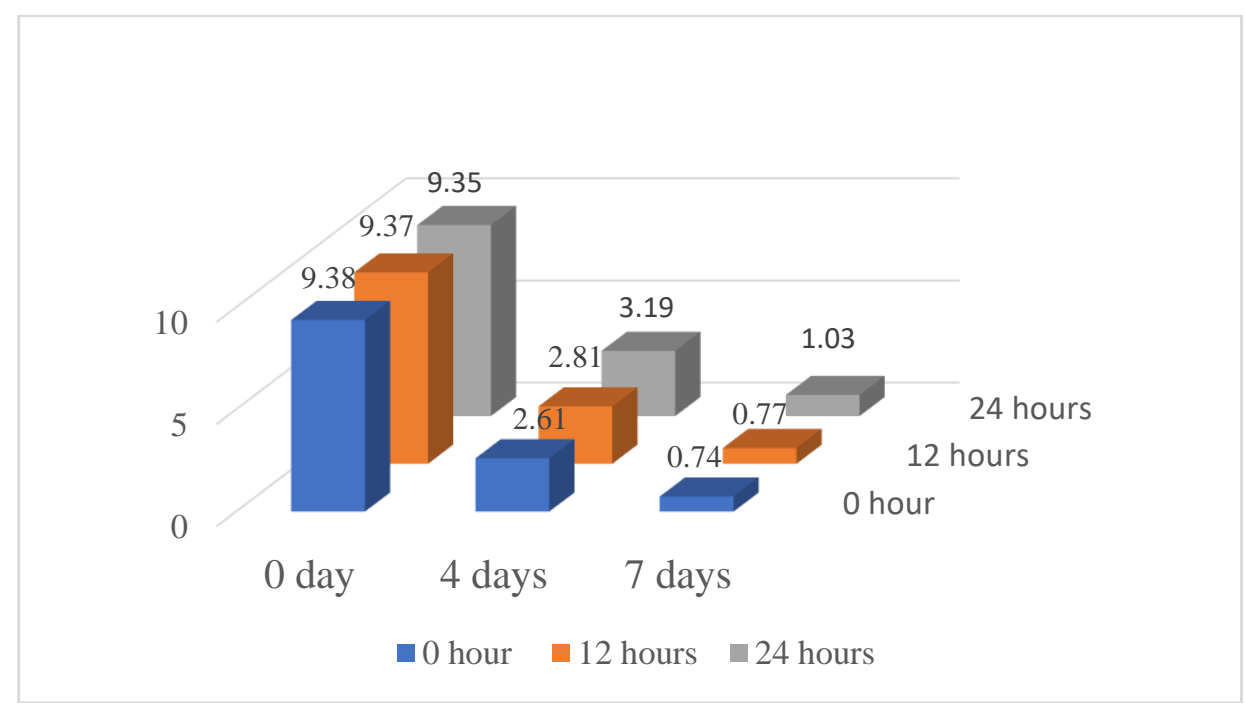

Fig. (1): Effect of different post-hatch feeding time on the remained yolk at different ages $(1 \mathrm{~g} / 100 \mathrm{~g} \mathrm{BW})$ 


\subsection{Body weight uniformity percent.}

Figure 2 shows the effect of different delay feeding time after chick placement on the body weight uniformity of chicks at 7,14 and 21 days of age. It shows that higher body weight uniformity percentage was recorded for chicks that were feed immediately after placement at 7 , 14 and 21 days of age being, $79.33 \%, 75.33$ and 72.33 , respectively. Followed by those delayed feeding for 12 and 24 hours. Better body weight uniformity percent for chicks fed diet immediately could prevent the accedent of dehydration mainly because of yolk sac utilization (Bergoug et al., 2013; Jacobs et al., 2016; Ozlu et al., 2017). Dehydration of chicks delayed in feeding cause slow growth and make body weight differ (Vieira \& Moran 1999a).

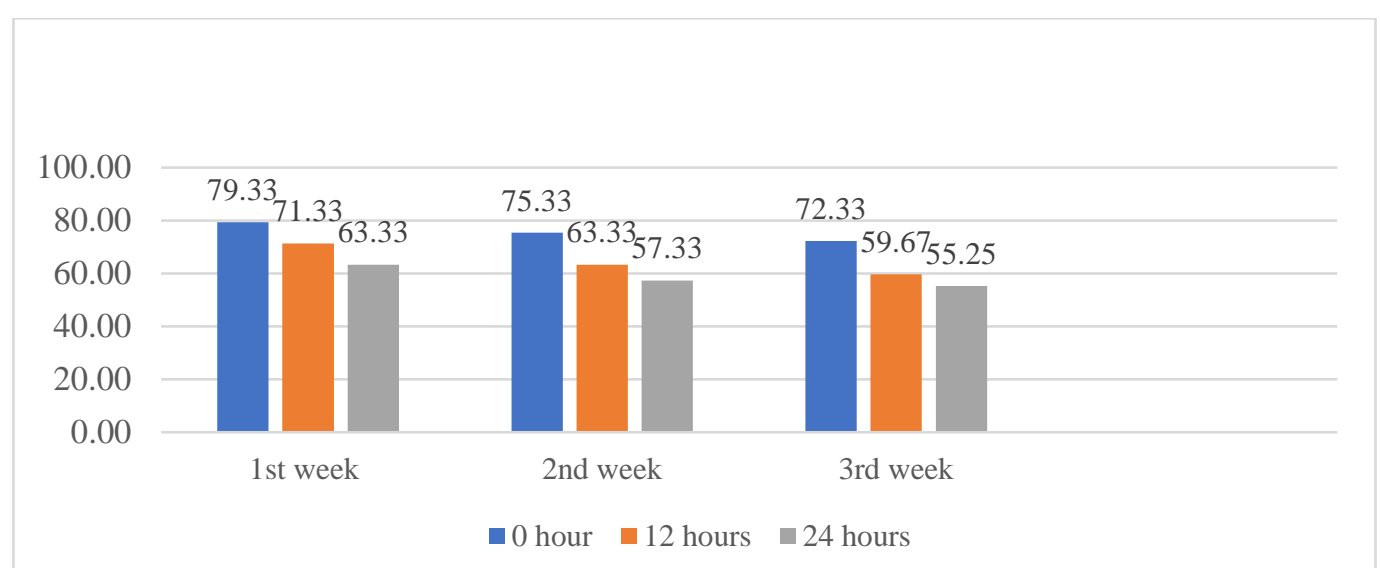

Fig. (2): Body weight uniformity \% of broiler chicks at different age exposed to various feeding time

\subsection{Performance parameters}

The influence of different delay feeding after placement on chicks' performance at different ages is presented in (table 2). Significantly $(\mathrm{p}<0,01)$ higher body weight, weight gain and feed intake were recorded for chickens that were fed immediately after placement at the farm followed by those that were fed after 12 hours and 24 hours after placement in the $1^{\text {st }}, 2^{\text {nd }}, 3^{\text {rd }}$ week and throughout the entire rearing period (21) days. At third week of age chicks that were fed immediately after placement significantly $(\mathrm{P}<0.05)$ recorded better feed conversion ratio compared to those that were fed after 24 hours of placement being 1.242 and 1.338, respectively. Throughout the 21 days of experimental period chicks on immediate fed after placement significantly $(\mathrm{P}<0.01)$ reported better feed conversion ratio (1.163) compared to those fed diet after 12 hours (1.213) and 24 hours (1.234). Chicks fed diet immediately (0 hours) significantly $\quad(\mathrm{P}<0.01) \quad$ recorded higher production index value compared to those that were delayed feeding for 12 and 24 hours being $368.2, \quad 318.59$ and 283.55 respectively. Livability percentage did not affect by the delayed feeding period after placement. These results were in agreement with the finding of
(Özlü et al., 2020) who found that delaying chicks feeding at placement for 12 hours significantly $(\mathrm{P}<0.01)$ affected the body weight. Moreover Cardeal et al., (2020) found that delaying chicks feeding for 24 hours significantly $(\mathrm{P}<0.01)$ decreased the body weight and feed intake compared to those fed diet after 3 hours at 21 days of age. However, in contrast Shafiei et al., (2018) reported that delayed feeding for 12 hours didn't significantly affect the body weight, weight gain and feed conversion ratio of broiler chicks. Moreover Bhanja et al., (2009) found that delayed feeding for 24 hours didn't significantly affect the body weight and feed conversion ratio of 21 days old broiler chicken compared to those that were fed immediately after placement.

Better performance for chicks fed immediately after arrival to the rearing hall may be due to that birds placed earlier had a longer feeding time than the birds placed after 12 and $24 \mathrm{~h}$, and the increased feed intake usually continued throughout life which clearly demonstrated a negative effect of body weight resulting in a reduction in feed intake, lower body weight and high mortality percent for delayed accesses to the fed were may be is associated dehydration and a shortage of 
available energy (Vieira and Moran, 1999b). furthermore, high level of the thyroid hormone for chicks fed immediately compared to other groups delayed fed for 12 and 24 hours. Zhan et al., (2007) summarized that concentration of thyroid hormones were closely correlated with growth performance and shift the energy metabolism of broilers.

Table (2): Effect of different post hatch feeding time after arrival to hall on the performance of broiler chicks at different age.

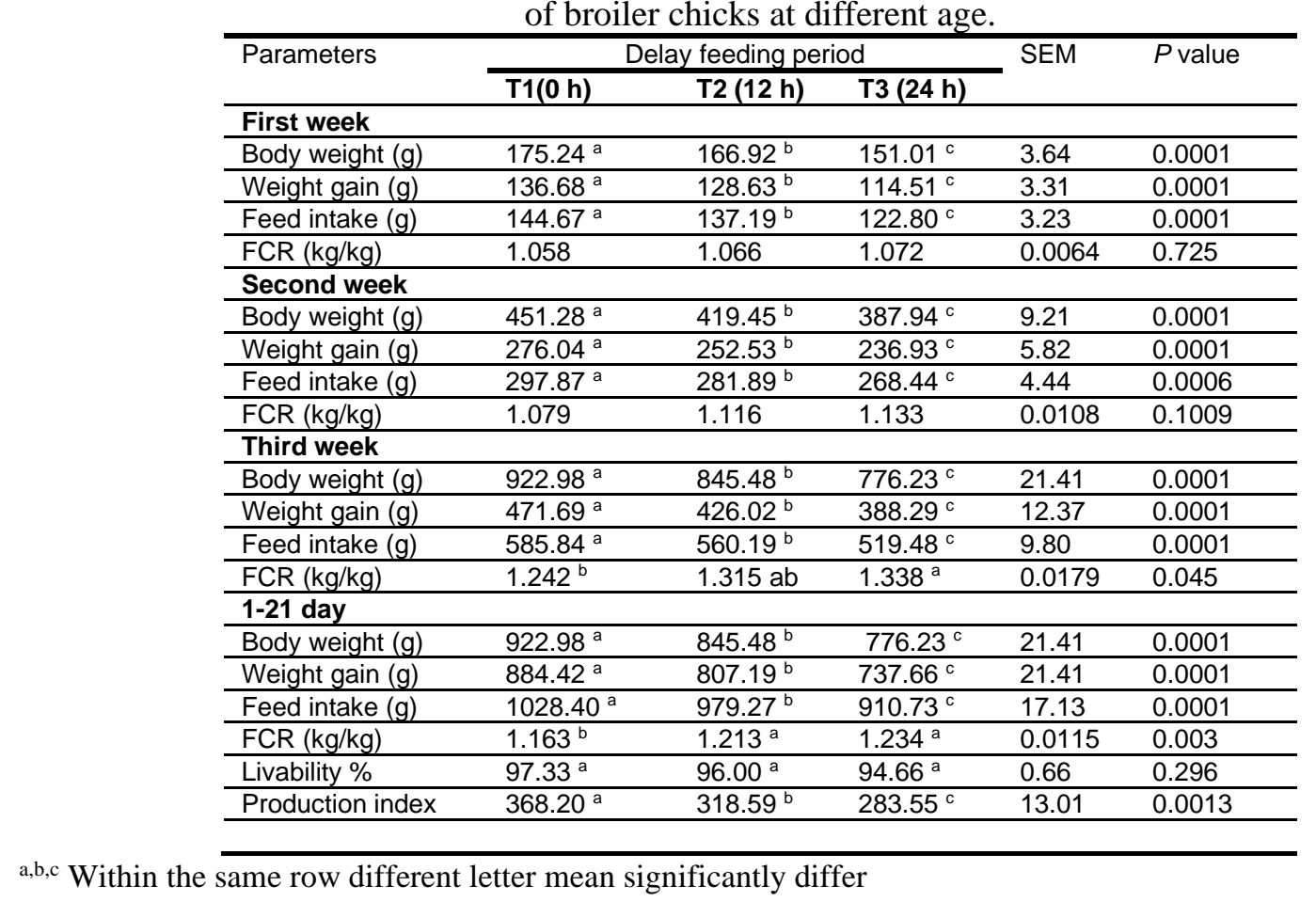

\subsection{Internal organs.}

The impact of delayed feeding on internal organs of broiler chicks at different ages is shown in (table 2). Significantly $(<0.01)$ longer small intestine during first, second and third week was recorded for chicks feed diet directly after arrived to rearing hall compared to those that were delayed feeding for 12 hour and 24 hours. The relative weight of the small intestine and gizzard at first week of age was significantly $(\mathrm{P}<0.01)$ higher in birds on early access to feed group compared for those delayed in feeding. At second week of age significantly $(\mathrm{P}<0.01)$ higher percent of liver and proventriculus to live body weight were recorded for delayed feeding group for 24 hours compared to others. Heart percent was significantly $(\mathrm{P}<0.01)$ higher for chicks delayed feeding for 12 hours compared to other groups. At third week of age significantly $(\mathrm{P}<0.01)$ higher liver percent was recorded for chicks fed diet at placement compared to delayed group. The relative weight of heart was significantly $(\mathrm{P}<0.01)$ higher in chicks that were delay feeding for 12 hours compared to other treatments. On the other hand, significantly $(\mathrm{P}<0.01)$ higher gizzard relative weight was recorded for chicks delayed feeding for 24 hours compared to other groups. The results were in line with the finding of Sözcü et al., (2020) who mentioned that delaying chicks feeding significantly $(\mathrm{P}<0.05)$ increased gizzard and heart percent of live body weight compared to early feeding.

However, in contrast kang et al., (2018) reported that delaying chicks feeding for 12 and 24 hours had no significant effect on the intestine length, intestine percent and gizzard percent compared to those chicks early accessed to fed at 21 days of age. Moreover, Shafiei et al., (2018) reported that delay feeding for 12 hours had no significant effect on the gizzard percent from live body weight of broiler compared to control. 
Table (2): Effect of different post hatch feeding time after arrival to hall on the internal organ of broiler chicks at different age.

\begin{tabular}{|c|c|c|c|c|c|}
\hline \multirow[t]{2}{*}{ Parameters } & \multicolumn{3}{|c|}{ Delay feeding period } & \multirow[t]{2}{*}{ SEM } & \multirow[t]{2}{*}{$P$ value } \\
\hline & T1(0 h) & T2 (12 h) & T3 (24 h) & & \\
\hline \multicolumn{6}{|l|}{ First week } \\
\hline Intestine length (cm) & $95.33^{a}$ & $89.66^{b}$ & $79.16^{c}$ & 1.744 & 0.0001 \\
\hline Intestine \% & $10.86^{a}$ & $9.60^{b}$ & $9.42^{b}$ & 0.189 & 0.003 \\
\hline Liver \% & 4.44 & 4.38 & 4.51 & 0.079 & 0.819 \\
\hline Heart \% & 0.82 & 0.86 & 0.80 & 0.017 & 0.302 \\
\hline Gizzard \% & $3.45 a$ & $3.04^{b}$ & $3.40^{a}$ & 0.069 & 0.019 \\
\hline Proventriculus \% & 1.01 & 0.90 & 0.87 & 0.026 & 0.085 \\
\hline \multicolumn{6}{|l|}{ Second week } \\
\hline Intestine length (cm) & $134.83^{a}$ & $125.83^{b}$ & $109.66^{c}$ & 2.591 & 0.0001 \\
\hline Intestine \% & 9.93 & 10.25 & 9.88 & 0.097 & 0.252 \\
\hline Liver \% & $2.37^{b}$ & $2.49^{b}$ & $2.72^{a}$ & 0.048 & 0.002 \\
\hline Heart \% & $0.75^{\mathrm{b}}$ & $0.84^{\mathrm{a}}$ & $0.79^{b}$ & 0.010 & 0.001 \\
\hline Gizzard \% & 1.69 & 1.78 & 1.75 & 0.019 & 0.188 \\
\hline Proventriculus \% & $0.62^{a}$ & $0.55 \mathrm{~b}$ & $0.60^{a}$ & 0.010 & 0.010 \\
\hline \multicolumn{6}{|l|}{ Third week } \\
\hline Intestine length (cm) & $159.98^{a}$ & $144.68^{b}$ & $132.16^{c}$ & 2.835 & 0.0001 \\
\hline Intestine \% & $6.79^{a}$ & $6.38^{b}$ & $6.74^{a}$ & 0.059 & 0.0021 \\
\hline Liver \% & $3.50^{a}$ & $2.84^{b}$ & $2.98^{b}$ & 0.074 & 0.0001 \\
\hline Heart \% & $0.96^{\mathrm{b}}$ & $1.03^{\mathrm{a}}$ & $0.80^{c}$ & 0.025 & 0.0001 \\
\hline Gizzard \% & $1.55^{c}$ & $1.73^{b}$ & $1.83^{a}$ & 0.031 & 0.0001 \\
\hline Proventriculus \% & 0.46 & 0.43 & 0.44 & 0.0068 & 0.138 \\
\hline
\end{tabular}

a,b,c Within the same row means not sharing the same subscript are different letter mean significantly differ

\subsection{Serum bio-chemicals}

Table 3 shows the effect of different delaying access to feed of day-old chicks on some serum biochemical parameters of broiler chicks at 21 days of age. Serum content of thyroid hormones $\mathrm{T} 3$ and $\mathrm{T} 4$ was significantly $(\mathrm{P}<0.01)$ higher for broiler chicks that were accessed earlier to the diet compared to those delayed feeding for 12 and 24 hours. The level of serum uric acid was significantly $(\mathrm{P}<0.01)$ higher in chicks delayed in feeding for 12 and 24 hours compared to control being 5.25, 5,40 and 4.45 respectively. The level of AST enzyme chicks that delayed in feeding for 12 hours was significantly $(\mathrm{P}<0.05)$ higher compared to control. All other serum biochemical parameters didn't significantly affected by delay feeding period. The results were in line with the finding of Kang et al., (2018) who reported that delay chicks feeding for 12 and 24 hours had no significant effect on serum cholesterol, triglycerides and AST enzyme at 21 days of age. Moreover Sözcü et al., (2020) reported that delaying chicks feeding cause significant decrease in the concentration of T3 hormone in the serum compared to control. Furthermore, Shafiei et al., (2018) observed that delay feeding of day old chicks for 12 hours had no significant effect on the serum cholesterol, high density lipoprotein, low density lipoprotein and triglyceride. While, significantly $(\mathrm{P}<0.01)$ increase serum uric acid concentration compared to control. On the other hand results were in contrast with findings of Shafiei et al., (2018) who recorded significantly $(\mathrm{P}<0.05$ lower serum albumin for chicks delayed feeding for 12 hours compared to control.

The changes in plasma thyroid hormones concentration in feed deprived broilers likely resulted from a shift in the balance between deiodination of $\mathrm{T} 4$ by hepatic $\mathrm{D} 1$ and $\mathrm{T} 3$ degradation by hepatic D3 deiodinases (Darras et al., 2000; Ryens et al., 2002). Gyorffy et al. (2009) found that during feed restriction, T3 concentration is lowered due to a decreased $\mathrm{T} 4$ activation and increased $\mathrm{T} 3$ inactivation. Furthermore, they show that hepatic type-I deiodinase (D1) is not affected by energy restriction, however, hepatic D2 is decreased on both transcriptional and enzyme activity levels. The thyroid hormones, including $\mathrm{T} 3$ and T4, are recognized as the key metabolic hormones of the body, with $\mathrm{T} 3$ being the most functionally active form. High serum uric acid concentration were recorded for chicks delayed feeding and this may be due to protein wastage, uric acid is a function of quality of protein in the ration whereby high levels indicated low protein efficiency utilization (Fafiolu, 2007) 
Table (3): Effect of different post hatch feeding time after arrival to hall on the serum biochemicals of broiler chicks at 21 days of age.

\begin{tabular}{|c|c|c|c|c|c|}
\hline \multirow[t]{2}{*}{ Parameters } & \multicolumn{3}{|c|}{ Delay feeding time } & \multirow[t]{2}{*}{ SEM } & \multirow[t]{2}{*}{$P$ value } \\
\hline & $\mathrm{T1}(\mathrm{O} \mathrm{h})$ & T2 (12 h) & T3 (24 h) & & \\
\hline Cholesterol (mg/dl) & 166.50 & 168.50 & 167.83 & 0.626 & 0.440 \\
\hline $\mathrm{HDL}(\mathrm{mg} / \mathrm{dl})$ & 57.33 & 57.50 & 56.50 & 0.641 & 0.812 \\
\hline $\mathrm{LDL}(\mathrm{mg} / \mathrm{dl})$ & 47.33 & 47.16 & 45.83 & 0.673 & 0.494 \\
\hline Triglyceride (mg/dl) & 39.83 & 38.83 & 37.66 & 0.800 & 0.666 \\
\hline T3 $(\mathrm{nmol} / \mathrm{ml})$ & $2.58^{a}$ & $2.25 \mathrm{~b}$ & $1.88^{c}$ & 0.076 & 0.0001 \\
\hline $\mathrm{T} 4(\mathrm{nmol} / \mathrm{ml})$ & $22.50^{a}$ & $17.16 \mathrm{~b}$ & $14.16^{\mathrm{c}}$ & 0.898 & 0.0001 \\
\hline Total protein & 2.6 & 2.66 & 2.63 & 0.042 & 0.940 \\
\hline Albumin (mg/dl) & 1.25 & 1.28 & 1.15 & 0.033 & 0.243 \\
\hline Globulin (mg/dl) & 1.38 & 1.38 & 1.48 & 0.029 & 0.293 \\
\hline Glucose (mg/dl) & 218.66 & 217.33 & 218.16 & 1.235 & 0.915 \\
\hline Uric acid (mg/dl) & $4.45^{b}$ & $5.26 \mathrm{a}$ & $5.40 \mathrm{a}$ & 0.113 & 0.0001 \\
\hline $\mathrm{ALT}(\mathrm{U} / \mathrm{L})$ & 7.63 & 7.78 & 7.78 & 0.117 & 0.850 \\
\hline AST (U/L) & $238.33 \mathrm{~b}$ & $271.16 \mathrm{a}$ & $248.00^{a b}$ & 5.656 & 0.040 \\
\hline
\end{tabular}

a,b,c Within the same row means not sharing the same subscript are different letter mean significantly differ AST, aspartate aminotransferase, T3, (triiodothyronine), T4 Thyroxine, AST, Aspartate Aminotransferase ALT, alanine Aminotransferase, HDL, high density lipoprotein, LDL, Low density lipoprotein.

\subsection{Jejunum histology}

The influence of various feeding period for day-old chicks after arrived to the rearing hall on the jejunum morphology is shown in (Table 4). Significantly $(\mathrm{P}<0.01)$ higher villus height, villi apical width, villi bas width, villi height to crypt depth and surface area were recorded for chicks that were early accessed to feed compared to those delayed for 12 and 24 hours. Crypt depth and muscle thickness were significantly $(\mathrm{P}<0.05)$ higher in chicks delayed feeding for 12 and 24 hours after chicks arrived to rearing hall compared to those accesses early to feed. The results were in line with the findings of Sözcü et al., (2020) who found that delay feeding of day-old chick significantly $(\mathrm{P}<0.05)$ reduced villi height compared to early feed group. The results were in contrast with the findings of Liu et al., (2020) who reported that delaying chicks feeding for 24 hours had no significant effect on the jejunum crypt depth and villi height to crypt depth compared to early feeding group. Furthermore, villi height was significantly $(\mathrm{P}<0.05)$ higher in birds that were immediately accessed to feed than those delayed feeding.

Early nutrition is a stimulus to the early development of GIT, early absorption of the yolk sac, improved performance and the health status of the birds later in life. In the post-hatch period, there is the rapid development of intestinal length, weight, and its enzymatical activities, where delay in feeding causes a reduction in development and expression of nutrient transporters affecting absorption of nutrients (Yegani \& Korver, 2008). Furthermore there is appositive correlation between intestine microflora and intestine developments (Dai et al., 2020) because early feeding significantly improves intestinal microflora compared to delay feeding (Binek et al., 2000; Lan et al., 2005). It is well-accepted that a lower crypt depth is indicative of faster tissue turnover and, perhaps, higher demand for new tissue (Tiwari et al., 2018; Jeurissen et al., 2002). Furthermore, it has been reported that a high intestinal villus is associated with a well-differentiated intestinal mucosa with high digestive and absorptive capabilities (Jeurissen et al., 2002). A metaanalysis study done for the effect of post-hatch delay feeding shows significant sub normality in the small intestine segment with reduced length and relative weight of duodenum, jejunum, and ileum, and shorter villus height and crypt depth of broiler chicks (De Jong et al., 2017)

Table (4): Influence of different delay feeding time on jejunum morphology of chicks at 21 days of age

\begin{tabular}{|c|c|c|c|c|c|}
\hline \multirow[t]{2}{*}{ Parameters } & \multicolumn{3}{|c|}{ Delay feeding time } & \multirow[t]{2}{*}{ SEM } & \multirow[t]{2}{*}{$P$ value } \\
\hline & T1 (0 h) & T2 (12 h) & T3 (24 h) & & \\
\hline Villi height $(\mu \mathrm{m})$ & $702.76^{a}$ & $577.88^{b}$ & $557.59^{b}$ & 5.31 & 0.0001 \\
\hline Villi apical width $(\mu \mathrm{m})$ & $87.40^{a}$ & $73.75^{b}$ & $39.95^{c}$ & 1.53 & 0.0001 \\
\hline Villi base width $(\mu \mathrm{m})$ & $88.64^{a}$ & $74.31^{b}$ & $48.45^{c}$ & 1.29 & 0.0001 \\
\hline Crypt depth $(\mu \mathrm{m})$ & $125.07^{c}$ & $139.07^{b}$ & $172.98^{a}$ & 2.34 & 0.0001 \\
\hline
\end{tabular}




\begin{tabular}{|c|c|c|c|c|c|}
\hline Muscle thickness $(\mu \mathrm{m})$ & $103.42^{b}$ & $115.70^{a}$ & $115.17^{a}$ & 2.26 & 0.043 \\
\hline Villi height/ crypt depth & $5.68^{a}$ & $4.61^{b}$ & $3.36^{c}$ & 0.11 & 0.0001 \\
\hline Surface area $\left(\mu \mathrm{m}^{2}\right)$ & $1415.52^{a}$ & $1160.28^{c}$ & $1274.31^{b}$ & 9.79 & 0.0001 \\
\hline
\end{tabular}

\section{CONCLUSION}

From the results of the current study it could be concluded that feeding day-old chicks directly after arrival to the rearing hall could improve broiler performance, thyroid hormone and intestine morphology at 21 days of age.

\section{REFERENCES.}

Bergoug, H., Burel, C., Guinebretiere, M., Tong, Q., Roulston, N., Romanini, C. E. B., ... \& Eterradossi, N. (2013). Effect of preincubation and incubation conditions on hatchability, hatch time and hatch window, and effect of post-hatch handling on chick quality at placement. World's Poultry Science Journal, 69(2), 313-334.

Bergoug, H., Guinebretiere, M., Tong, Q., Roulston, N., Romanini, C. E. B., Exadaktylos, V., and Michel,V. (2013). Effect of transportation duration of 1-day-old chicks on postplacement production performances and pododermatitis of broilers up to slaughter age. Poultry science, 92(12), 3300-3309.

Bhanja, S. K., Anjali Devi, C., Panda, A. K., \& Shyam Sunder, G. (2009). Effect of post hatch feed deprivation on yolk-sac utilization and performance of young broiler chickens. AsianAustralasian Journal of Animal Sciences, 22(8), 1174-1179.

Binek, M., Borzemska, W., Pisarski, R., Kosowska, G., Malec, H., \& Karpińska, E. (2000). Evaluation of the efficacy of feed providing on development of gastrointestinal microflora of newly hatched broiler chickens. Archiv für Geflügelkunde, 64(4), 147-151.

Cardeal, P. C., Rocha, J. S. R., Pompeu, M. A., Pereira, L. F. P., Saldanha, M. M., Baião, N. C., and Lara, L. J. C. (2020). Effects of placement time on performance and gastrointestinal tract growth of male broiler chickens. Revista Brasileira de Zootecnia, 49.
Dai, D., Wu, S. G., Zhang, H. J., Qi, G. H., \& Wang, J. (2020). Dynamic alterations in early intestinal development, microbiota and metabolome induced by in ovo feeding of Larginine in a layer chick model. Journal of animal science and biotechnology, 11(1), 1-16.

Darras, V. M., Van der Geyten, S., \& Kühn, E. R. (2000). Thyroid hormone metabolism in poultry. BASE.

De Jong, I. C., van Riel, J., Bracke, M. B., \& van den Brand, H. (2017). A'meta-analysis' of effects of post-hatch food and water deprivation on development, performance and welfare of chickens. PloS one, 12(12), e0189350.

Duncan, B.D. (1955). Multiple range and multiple Ftest: Biometrics, 11:1-42.

Esteban, S., Moreno, M., Rayo, J. M., \& Tur, J. A. (1991). Gastrointestinal emptying in the final days of incubation of the chick embryo. British poultry science, 32(2), 279284.

Fafiolu, A. O. (2007). Utilization of enzyme (ROVABIO®) supplemented undecortilated sun-fl ower seed meal based diets by domestic chickens (Ph. D. thesis).

Ghanem, H. M., Lashen, S. E. S., Mahmoud, R. E. S., and Azzam, M. (2018). Productive performance anhistological evaluation of delayed post hatch feed access broilers fed threonine supplemented diet. Asian J. Anim. Vet. Adv. 13:136-143.

Gonzales, E., Kondo, N., Saldanha, E. S., Loddy, M. M., Careghi, C., and Decuypere, E. (2003). Performance and physiological parameters of broiler chickens subjected to fasting on the neonatal period. Poultry Science, 82(8), 12501256.

Györffy, A., Sayed-Ahmed, A., Zsarnovszky, A., Frenyó, V., Decuypere, E., \& Bartha, T. (2009). Effects of energy restriction on thyroid 
hormone metabolism in chickens. Acta Veterinaria Hungarica, 57(2), 319-330.

Iji, P. A., Hughes, R. J., Choct, M., \& Tivey, D. R. (2001). Intestinal structure and function of broiler chickens on wheat-based diets supplemented with a microbial enzyme. Asian-Australasian Journal of Animal Sciences, 14(1), 54-60.

Jacobs, L., Delezie, E., Duchateau, L., Goethals, K., Ampe, B., Lambrecht, E., and Tuyttens, F. A. (2016). Effect of post-hatch transportation duration and parental age on broiler chicken quality, welfare, and productivity. Poultry Science, 95(9), 1973-1979.

Jeurissen, S.H., Lewis, F., van der Klis, J. D., Mroz, Z., Rebel, J. M., \& Ter Huurne, A. A. (2002). Parameters and techniques to determine intestinal health of poultry as constituted by immunity, integrity, and functionality. Current issues in intestinal microbiology, 3(1), 1-14.

Kang, H. K., Bang, H. T., Kim, C. H., Jeon, J. J., Kim, H. S., Suh, S. W., and Park, S. B. (2018). Effects of early posthatch feeding on growth, organ development, and blood biochemical profile in broiler chickens. Canadian Journal of Animal Science, 99(2), 418-424.

Lan, Y., Verstegen, M. W. A., Tamminga, S., \& Williams, B. A. (2005). The role of the commensal gut microbial community in broiler chickens. World's poultry science journal, 61(1), 95-104.

Lilburn, M. S., \& Loeffler, S. (2015). Early intestinal growth and development in poultry. Poultry Science, 94(7), 1569-1576.

Liu, K., Jia, M., \& Wong, E. A. (2020). Delayed access to feed affects broiler small intestinal morphology and goblet cell ontogeny. Poultry science, 99(11), 5275-5285.

Lourens, A., Van den Brand, H., Meijerhof, R., and Kemp, B. (2005). Effect of eggshell temperature during incubation on embryo development, hatchability, and post hatch development. Poultry science, 84(6), 914-920.
Moran Jr, E. T., \& Reinhart, B. S. (1980). Poult yolk sac amount and composition upon placement: effect of breeder age, egg weight, sex, and subsequent change with feeding or fasting. Poultry science, 59(7), 1521-1528.

Mustafa, M. M., Karadas, F., \& Tayeb, I. T. (2021). Adding different levels of turmeric powder and curcumin in the diet on some serum biochemical of broiler reared under normal and heat stress conditions. Iraqi Journal of Agricultural Sciences :52(1):10-19

Noy, Y., and Sklan, D. (1998a). Yolk utilisation in the newly hatched poult. British poultry science, 39(3), 446-451.

Özlü, S., Torun, E. Y., Shiranjang, R., Akan, M., \& Elibol, O. (2017). The effect of post-hatch holding time on yolk sac absorption and ND titer of day old broiler chicks. In WVPA XXth Congress, Edinburgh, UK, September (pp. 48).

Özlü, S., Uçar, A., Romanini, C. E. B., Banwell, R., and Elibol, O. (2020). Effect of post hatch feed and water access time on residual yolk and broiler live performance. Poultry Science, 99(12), 6737-6744.

Panda, A. K., Bhanja, S. K., and Sunder, G. S. (2015). Early post hatch nutrition on immune system development and function in broiler chickens. World's Poultry Science Journal, 71(2), 285-296.

Reyns, G. E., Janssens, K. A., Buyse, J., Kühn, E. R., \& Darras, V. M. (2002). Changes in thyroid hormone levels in chicken liver during fasting and refeeding. Comparative Biochemistry and Physiology Part B: Biochemistry and Molecular Biology, 132(1), 239-245.

SAS Institute. (2010). SAS/STAT user's guide. Version 9.1. Cary: SAS institute.

Shafiei, A., Khavarinezhad, S., Javandel, F., Nosrati, M., Seidavi, A., and Diarra, S. S. (2018). Effects of duration of early feed withdrawal and re-feeding on growth, carcass traits, plasma constituents and intestinal microflora of broiler chickens. Journal of Applied Animal Research, 46(1), 1358-1362. 
Shinde, A. S., Goel, A., Mehra, M., Rokade, J., Bhadauria, P., Mandal, A. B., and Bhanja, S. K. (2015). Delayed post hatch feeding affects performance, intestinal morphology and expression pattern of nutrient transporter genes in egg type chickens. Journal of Nutrition \& Food Sciences, 5(3), 1.

Simon, K., de Vries Reilingh, G., Bolhuis, J. E., Kemp, B., and Lammers, A. (2015). Early feeding and early life housing conditions influence the response towards a noninfectious lung challenge in broilers. Poultry Science, 94(9), 2041-2048.

Simon, K., de Vries Reilingh, G., Kemp, B., and Lammers, A. (2014). Development of ileal cytokine and immunoglobulin expression levels in response to early feeding in broilers and layers. Poultry science, 93(12), 30173027.

Sözcü, A., Ipek, A., Kahraman, M. M., and Ipek, V. (2020). The effects of hatching time and feed access time on chick quality, organ development, blood parameters, and intestinal morphology in broilers. Turkish Journal of Veterinary and Animal Sciences, 44(4), 763773.

Speake, B. K., Noble, R. C., \& Murray, A. M. (1998). The utilization of yolk lipids by the chick embryo. World's Poultry Science Journal, 54(4), 319-334.
Tiwari, U. P., Chen, H., Kim, S. W., \& Jha, R. (2018). Supplemental effect of xylanase and mannanase on nutrient digestibility and gut health of nursery pigs studied using both in vivo and in vitro models. Animal Feed Science and Technology, 245, 77-90.

Vieira, S. L., \& Moran Jr, E. T. (1999a). Effects of delayed placement and used litter on broiler yields. Journal of Applied Poultry Research, 8(1), 75-81.

Vieira, S. L., \& Moran, E. T. (1999b). Effects of egg of origin and chick post-hatch nutrition on broiler live performance and meat yields. World's Poultry Science Journal, 55(2), 125-142.

Williams, M. A., Lallo, C. H. O., \& Sundaram, V. (2021). The Effect of Early Post Hatch Feeding Times on the Growth and Development of the Gastrointestinal Tract of Mule Ducklings to Five Days of Age. Brazilian Journal of Poultry Science, 23.

Yegani, M., \& Korver, D. R. (2008). Factors affecting intestinal health in poultry. Poultry science, 87(10), 2052-2063.

Zhan, X. A., Wang, M., Ren, H., Zhao, R. Q., Li, J. X., \& Tan, Z. L. (2007). Effect of early feed restriction on metabolic programming and compensatory growth in broiler chickens. Poultry Science, 86(4), 654-660. 